\title{
Histopathological findings on innate responses of white spot disease positive Penaeus monodon (Fabricius) under semi-intensive culture
}

\section{A K Sahoo ${ }^{1,2}$, P C Thakur ${ }^{1,3}, K_{\text {M Shankar }}{ }^{1}$, C V Mohan ${ }^{4}$, S R Krupesha Sharma ${ }^{1,5}$ and F Corsin ${ }^{6}$}

1 Fish Pathology and Biotechnology Laboratory, Department of Aquaculture, College of Fisheries, Karnataka

Veterinary, Animal and Fishery Science University, Mangalore, India

2 Central Inland Fisheries Research Institute, Barrackpore, Kolkata, West Bengal, India

3 University of Pittsburgh School of Medicine, Pittsburgh, PA, USA

4 Network of Aquaculture Centres in Asia Pacific (NACA), Kasetsart University Campus, Bangkok, Thailand

5 Central Marine Fisheries Research Institute KARWAR, Karnataka, India

6 Aquaculture Program and Spices Production, IDH, The Sustainable Trade Initiative, Hanoi, Vietnam

Keywords: innate defence response, Penaeus monodon, white spot disease.

White spot disease (WSD) is caused by white spot syndrome virus (WSSV), which is a bacilliform, non-occluded, enveloped, double-stranded (ds) DNA virus and belongs to the family Nimaviridae and genus Whispovirus (Vlak et al. 2005). In recent years, intensive studies on the virus have been made, particularly with respect to its organization, morphogenesis, pathology and pathogenesis (Escobedo-Bonilla et al. 2008). Shrimps, like other invertebrates, lack a true adaptive immune system but have developed effective mechanisms for detecting and eliminating pathogens, which depend primarily on innate immune system (Loker et al. 2004). Haemocytes constitute the first line of internal defence against invading microorganisms. They are crucial in the immune responses of crustaceans and are capable of cell agglutination, phagocytosis, encapsulation, nodule

Correspondence A K Sahoo, Central Inland Fisheries Research Institute, Barrackpore, Kolkata, West Bengal 700120, India (e-mail: amiya7@gmail.com) and P C Thakur, University of Pittsburgh School of Medicine, Pittsburgh, PA 15213, USA (e-mail: pcthakur01@gmail.com) formation and mediation of cytotoxicity (Soderhall 1999; Johansson et al. 2000). These cells are also involved in synthesis, storage, activation and discharge of pro-enzymes and substrates of the clotting, and prophenoloxidase (proPO) cascades. Apoptosis has been proposed as the main antiviral mechanisms in invertebrates (Rhee, Kim \& Park 2002). A comprehensive review of shrimp humoral responses, binding between shrimp and viral structural proteins and intracellular responses was conducted by Flegel \& Sritunyalucksana (2011). In recent years, much information has been generated on the immune response genes and proteins involved in WSSV pathogenesis (Maningas et al. 2008). Under experimental conditions, there are reports of shrimp innate immune responses in terms of dramatic decline in circular haemocytes, changes in haemocyte structure and failure of hemolymph clotting in response to WSSV (Sahul Hameed et al. 2006; Arts et al. 2007). In the present study, we report on innate defence responses in Penaeus monodon (Fabricius) with clinical WSD in a semi-intensive culture system. This study was a part of a larger epidemiological study on WSD carried out in the shrimp farms of Karnataka, West coast of India 
(Thakur et al. 2002; Turnbull et al. 2005; Sahoo et al. 2010).

During this longitudinal observational study, data related to pond preparation, water quality, stocking of post-larvae, shrimps at middle of culture (6 week after stocking) and at harvest were collected directly by the research team. The study aimed at collecting and analysing a total of 100 shrimp samples per pond. This sampling method allowed the estimation of the prevalence of any disease characteristics in the shrimp population with $95 \%$ confidence and $10 \%$ precision. During the middle of the culture period at 6-week poststocking, Penaeus monodon (100/pond) were randomly collected from a total of 68 ponds. We further randomly selected 40 ponds of these 68 ponds for the analyses. In each pond, the sample was grouped into 10 subsamples of 10 shrimps each and preserved in 10\% phosphate-buffered formalin. One subsample (containing 10 shrimps) was randomly selected from each pond, leading to a total number of 400 shrimps. Longitudinally bisected cephalothoracic portion of each shrimp was used for histological processing and diagnosis. The samples were processed for histopathology following standard protocol outlined by Lightner (1996). A minimum of three good sections of $5 \mu \mathrm{m}$ thickness per shrimp were stained in haematoxylin and eosin (H\&E). The stained sections were examined for evidences of WSSV inclusions and classified as light, moderate and severe level of clinical WSD by standard severity grading method (Lightner 1996). In addition, the presence of chronic inflammatory lesions (CIL) in the form of haemocytic nodules, typical of bacterial infection, was examined. Data analysis was conducted by considering individual shrimp as statistical units. Data were analysed by $2 \times 2$ contingency tables Yates-corrected chi-square test. A $P$-value of 0.05 or lower was considered as significant. All $2 \times 2$ tables were tested using Epi Info 7.0 (Centre for Disease Control and Prevention, USA/ World Health Organization, Atlanta).

Distinct pathological features of WSD were observed in 40 of 400 shrimps. Of the 40 , innate responses in the form of haemocytes aggregation were observed in 10 shrimps with light WSD and hemolymph clots in eight shrimps with moderate WSD (Figs 1 \& 2). Hemolymph clots with associated haemocytes were extensive in the muscle cells of rostrum, pleopods and periopods with conspicuous eosinophilic viral inclusions. Cells

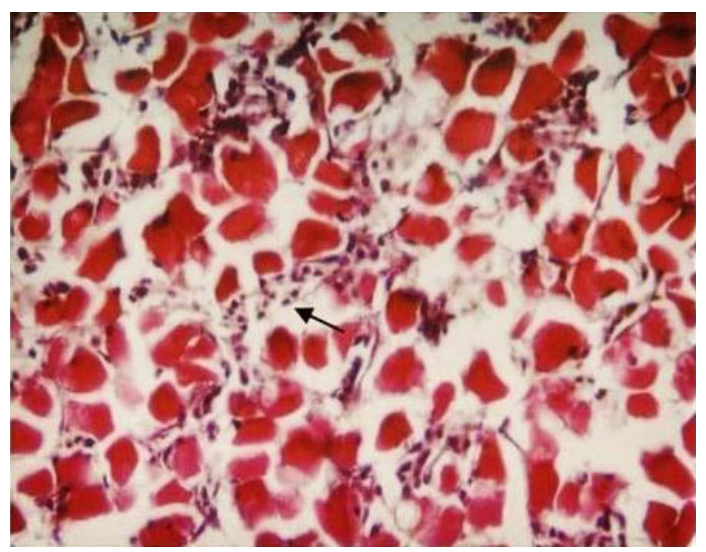

Figure 1 Penaeus monodon, longitudinal section of pleopod of a WSD shrimp showing considerable haemocytes aggregation (arrow) (H\&E, 200×).

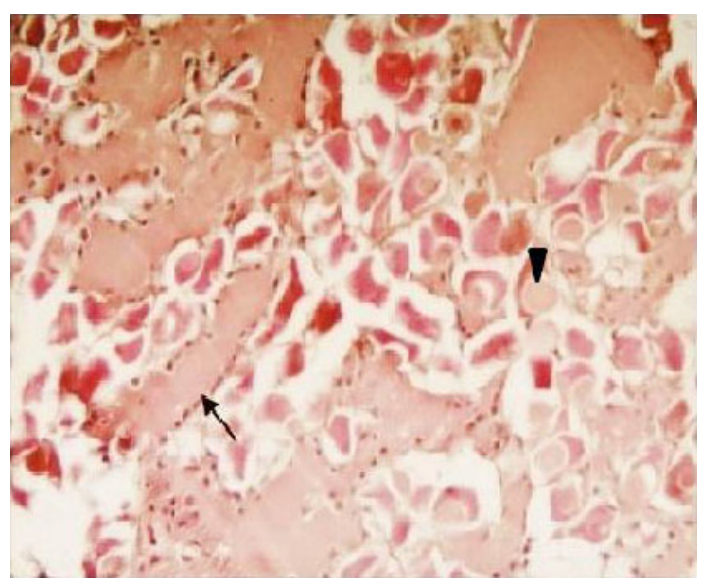

Figure 2 Penaeus monodon, longitudinal section of rostrum of a WSD shrimp showing conspicuous haemolymph clots (arrow) and muscle cells with eosinophilic intranuclear inclusions (arrow head) (H\&E, 400×).

with basophilic intranuclear inclusions and cells devoid of nucleus were noticed in shrimps with severe WSD (Fig. 3 and Table 1). However, four shrimps negative for WSD by histopathology showed innate responses in the form of haemocytes aggregations. Statistical analysis showed a high significant association between the shrimps with clinical WSD and shrimps showing innate responses $(P=0.0000000000)$ (Table 2$)$.

Shrimp samples were collected at 6 -week poststocking to understand the WSD status during the middle of the crop cycle and their possible effect in disease outbreak (Sahoo et al. 2010). Of the 400 shrimps examined, 40 shrimps were 


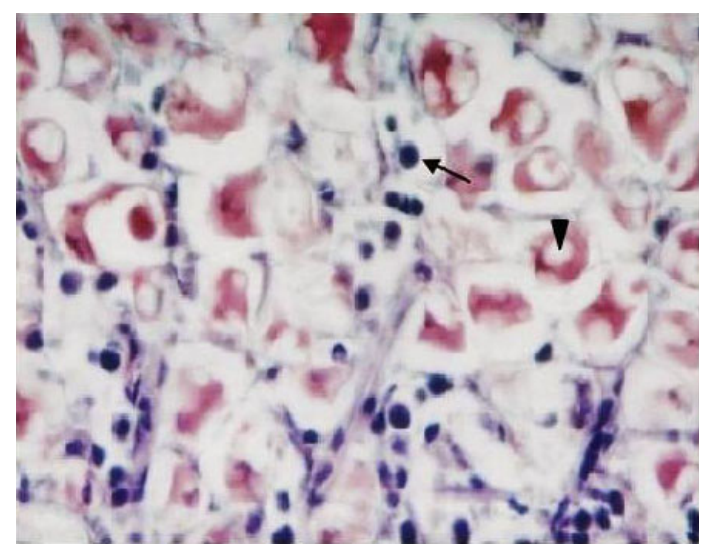

Figure 3 Penaeus monodon, muscle cells of a WSD shrimp showing basophilic intranuclear inclusions (arrow) and cells devoid of nucleus (arrow head) (H\&E, 400×).

Table 1 Category of white spot disease (WSD) shrimps, Penaeus monodon, and innate responses at individual level

\begin{tabular}{lcc}
\hline & \multicolumn{2}{l}{ Response (Innate) } \\
\cline { 2 - 3 } Level of WSD & With & Without \\
\hline Light & 10 & 11 \\
Moderate & 8 & 5 \\
Severe & 0 & 6 \\
\hline
\end{tabular}

Table 2 Association between shrimp innate responses and WSD status at individual shrimp level; $P$ : probability value at 95\% CI $(P<0.05)$ (Epi Info 7$)$

\begin{tabular}{llrl}
\hline & \multicolumn{2}{l}{ WSD } \\
status & & \\
\cline { 2 - 3 } Shrimp innate responses & + & - & Statistics \\
\hline+ & 18 & 4 & $P=0.0000000000$ \\
- & 22 & 356 & \\
\hline
\end{tabular}

positive for clinical WSD with light, moderate or severe level of the disease. Although there were no evidences of CIL in the representative shrimps associated with bacterial infection, innate responses in the form of haemocytes aggregation towards the cuticular cell layer were observed in shrimps with light WSD. It is well known that cuticular epithelium, connective tissues and haematopoietic tissues are the target sites of WSSV (Wongteerasupaya et al. 1995). van de Braak et al. (2002) documented that during WSSV infection, there is a strong decline in free circulating haemocytes. It is believed that these haemocytes leave the circulation and migrate towards virus-infected cells. As we observed haemocytes aggregation only in shrimps with light WSD, it is possible that such an innate response may be one of the primary responses to the WSSV-infected cells. Furthermore, hemolymph clots in the spongy connective tissues of rostrum and periopods associated with haemocytes and particularly with eosinophilic viral inclusions in shrimp is quite interesting. The clotting reactions in crustacean are medicated by transglutaminase (TGase) (Wang et al. 2001), which are $\mathrm{Ca}_{2}{ }^{+}$-dependent enzymes. These enzymes are capable of forming covalent bonds between the side chains of free lysine and glutamine residues of clotting protein. In shrimps, the level of TGase in both haemocytes and lymphoid organs dramatically decreases at the late stages of WSSV infection, which may account for the failure of clotting reaction (Liu et al. 2007). In our study, the pathological tissues show clots in the moderate level of infected cells with eosinophilic virus inclusion bodies. On the other hand, in severe WSD shrimps, cells devoid of nucleus and cells with developed basophilic intranuclear inclusions bodies were observed. The early phases of WSSV inclusions are eosinophilic and later change to fully developed basophilic intranuclear inclusion bodies (Lightner 1996). Hence, we hypothesize that the clotting mechanism may occur only during the early to moderate level of WSSV infection, and not in the severe cases. Although our data are consistent with the hypothesis that the clotting is strongly associated with early stage of WSSV infection, we cannot completely rule out the possibility that the observed innate responses may have been a preliminary host response to tissue damage caused by WSSV or low level of secondary pathogens. In either case, the differential immune responses observed during various stages of WSD progression in this epidemiological study are quite intriguing. Clotting has been most studied in freshwater crayfish and horseshoe crab, and it is observed that hemolymph of horseshoe crab is extremely sensitive to minute amount of bacterial lipopolysaccharides that results in coagulin (Tanaka \& Iwanaga 1993). It is known that clotting cascade provides a dual action, that is, clotting and production of antimicrobial substances against invading agents (Theopold et al. 2004), and can proceed independently of melanization (Scherfer et al. 2004). We hypothesize that the hemolymph clots that 
are mainly restricted to connective tissues of appendages may further progress to melanin formation after rostrum or antennal cut.

In the present study, while investigating the WSD status in shrimps during the middle of culture period, a strong association between innate defence responses in the form of haemocytes aggregation and hemolymph clots was observed in the light of moderate clinical WSD shrimps. Although there are reports of haemocytes migration towards the WSSV-infected cells as an immune response in shrimp, hemolymph clots with eosinophilic viral inclusion bodies in connective tissues as an innate response is interesting and of first record. As molecular information on clotting mechanism in shrimp to WSSV is limited, our pathological results particularly at the early and moderate stages of WSSV infection would secure a greater molecular understanding of these processes during the infection.

\section{Acknowledgements}

The samples used in this study were obtained from an epidemiological project funded by the Department for International Development through project RT 7051 of the strategy for Research on Renewable Natural Resource Programme.

\section{Publication History}

Received: 3 August 2013

Revision received: 15 October 2013

Accepted: 15 October 2013

This paper was edited and accepted under the Editorship of Professor Ron Roberts.

\section{References}

Arts J.A.J., Taverne-Thiele A.J., Savelkoul H.F.J. \& Rombout J.H.W.M. (2007) Hemocyte reactions in WSSV immersion infected Penaeus monodon. Fish \& Shellfish Immunology 23, 164-170.

van de Braak C.B.T., Botterblom M.H.A., Huisman E.A., Rombout J.H.W.M. \& van der Knaap W.P.W. (2002) Preliminary study on haemocyte response to white spot syndrome virus infected in black tiger shrimp. Diseases of Aquatic Organisms 51, 149-155.

Escobedo-Bonilla C.M., Alday-Sanz V., Wille M., Sorgeloos P., Pensaert M.B. \& Nauwynck H.J. (2008) A review on the morphology, molecular characterization, morphogenesis and pathogenesis of white spot syndrome virus. Journal of Fish Diseases 31, 1-18.
Flegel T.W. \& Sritunyalucksana K. (2011) Shrimp molecular responses to viral pathogens. Marine Biotechnology 13, 587-607.

Johansson M.W., Keyser P., Sritunyalucksana K. \& Soderhall K. (2000) Crustacean haemocytes and haematopoiesis. Aquaculture 191, 45-52.

Lightner D.V. (1996) A Handbook of Pathology and Diagnostic Procedures for Diseases of Penaeid Shrimp. World Aquaculture Society, Baton Rouge, LA, USA.

Liu Y.C., Li F.H., Wang B., Dong B., Zhang Q.L., Luan W., Zhang X.J. \& Xiang J.H. (2007) A transglutaminase from Chinese shrimp, Fenneropenaeus chinensis, full length cDNA cloning, tissue localization and expression profile after challenge. Fish \& Shellfish Immunology 22, 576-588.

Loker E.S., Adema C.M., Zhang S.M. \& Kepler T.B. (2004) Invertebrate immune systems-not homogeneous, not simple, not well understood. Immunology Review 198, 10-24.

Maningas M.B.B., Kondo H., Hirono I., Saito T. \& Aoki T. (2008) Essential function of transglutaminase and clotting protein in shrimp immunity. Molecular Immunology $\mathbf{4 5}$, 1269-1275.

Rhee W.J., Kim E.J. \& Park T.H. (2002) Silkworm hemolymph as a potent inhibitor of apoptosis in Sf9 cells. Biochemical and Biophysical Research Communications 295, 779-783.

Sahoo A.K., Mohan C.V., Shankar K.M., Corsin F., Turnbull J.F., Thakur P.C., Hao N.V., Morgan K.L. \& Padiyar A.P. (2010) Clinical White spot disease status in Penaeus monodon during the middle of the culture period - its epidemiological significance. Journal of Fish Diseases 33, 609-615.

Sahul Hameed A.S., Sarathi M., Sudhakaran R., Balasubramanian G. \& Syed Mustha S.(2006) Quantitative assessment of apoptotic hemocytes in white spot syndrome virus (WSSV)- infected penaeid shrimp, Penaeus monodon and Penaeus indicus, by flow cytometric analysis. Aquaculture 256, 111-120.

Scherfer C., Karlsson C., Loseva O., Bidla G. \& Goto A. (2004) Isolation and characterization of hemolymph clotting factors in Drosophila melanogaster by a pullout method. Current Biology 14, 25-29.

Soderhall K. (1999) Invertebrate immunity. Developmental and Comparative Immunology 23, 263-442.

Tanaka S. \& Iwanaga S. (1993) Limulus test for detecting bacterial endotoxins. Methods Enzymology 223, 358-364.

Thakur P.C., Corsin F., Turnbull J.F., Shankar K.M., Hao N.V., Padiyar P.A., Madhusudhan M., Morgan K.L. \& Mohan C.V. (2002) Estimation of prevalence of white spot syndrome virus (WSSV) by polymerase chain reaction in Penaeus monodon post larvae at time of stocking in shrimp farms of Karnataka, India: a population based study. Diseases of Aquatic Organisms 49, 235-243.

Theopold U., Schmidt O., Soderhall K. \& Dushay M.S. (2004) Coagulation in arthropods: defense, wound closer and healing. Trends in Immunology 25, 289-294.

Turnbull J.F., Corsin F., Mohan C.V., Padiyar P.A., Thakur P.C., Madhusudan M., Hao N.V. \& Morgan K.L. (2005) Optimising emergency harvest strategy for white spot disease 
in a semi-intensive Penaeus monodon culture system in Karnataka, India. Diseases in Asian Aquaculture V, 405-414.

Vlak J.M., Bonami J.R., Flegel T.W., Kou G.H., Lightner D.V., Lo C.F., Loh P.C. \& Walker P.J. (2005) Nimaviridae. In: Virus Taxonomy VIIIth Report of the International Committee on Taxonomy of Viruses (eds by C.M. Fauquet, M.A. Mayo, J. Maniloff, U. Desselberger \& L.A. Ball), pp. 187-192. Elsevier/Academic Press, London.

Wang R., Liang Z., Hall M. \& Soderhall K. (2001) A transglutaminase involved in the coagulation system of the freshwater crayfish. Pacifastacus leniusculus. Tissue

localization and CDNA cloning. Fish \& Shellfish Immunology 11, 623-637.

Wongteerasupaya C., Vickers J.E., Sriurairatana S., Nash G.L., Akarajamorn A., Boonsaeng V., Panyim S., Tassanakajon A., Withyachumnarnkul B. \& Flegel T.W. (1995) A non-occluded, systemic baculovirus that occurs in cells of ectodermal and mesodermal origin and causes high mortality in the black tiger prawn Penaeus monodon. Diseases of Aquatic Organisms 21, 69-77. 
This document is a scanned copy of a printed document. No warranty is given about the accuracy of the copy. Users should refer to the original published version of the material. 